\title{
Chromosomal Behaviour and Seed Production in Chlorophytum comosum (Liliaceae)
}

\author{
Maria Suely Pagliarini, Maricy B. Pissinatti and Neide Silva \\ Departamento de Biologia Celular e Genética, Universidade Estadual de \\ Maringá, 87020-900, Maringá-Paraná-Brasil
}

Accepted August 4, 1993

The genus Chlorophytum comprises about 234 species distributed in tropical and subtropical regions, most of them occurring in Africa, its possible centre of origin (Patil et al. 1987). Many species of this genus have been studied from cytotaxonomic and cytogeographic points of view (Baldwin and Speese 1951, Mukherjee 1957, Naik 1976, 1977). The basic chromosome number for the genus has been suggested to be $x=8$ and 7 , possibly derived as a secondary number from $x=4$ (Patil et al. 1987). Some species of Chlorophytum are being studied in terms of economic and medicinal aspects (Tarafder 1983, Wolverton et al. 1984). C. comosum is widely used in gardens in Brazil. Effects of magnesium sulphate and dye industry waste water on meiotic abnormalities were studied in C. heyneanum (Abraham and Nair 1990) and C. amaniense (Somashekar 1987), respectively. In this paper we describe the meiotic behaviour of $C$. comosum not submitted to any treatment.

\section{Materials and methods}

The plants of $C$. comosum belong to the gardens of the University of Maringa where the soil is a "Terra roxa estruturada" (typic paleudalf) (EMBRAPA 1984). Chemical analysis showed that the soil presents low acid nature $\left(\mathrm{pH} \mathrm{CaCl}_{2}=4.5\right)$, with low aluminium saturation $\left(\mathrm{Al}^{3}=0.10 \mathrm{mEq} / 100 \mathrm{ml}\right.$ soil $)$ in the ability to exchange cations $\left(\mathrm{H}^{+}+\mathrm{Al}^{+3}=4.80\right)$, medium phosphorus levels $(\mathbf{P}=9 \mathrm{ppm})$, high calcium and magnesium content $\left(\mathrm{Ca}^{+2}+\mathrm{Mg}^{1{ }^{2}}=7.66\right.$ $\mathrm{mEq} / 100 \mathrm{ml}$ soil $)$, potassium $\left(\mathrm{K}^{+}=0.16 \mathrm{mEq} / 100 \mathrm{ml}\right.$ soil) and high organic matter content (organic $\mathrm{C}=1.88 \%$ ). According to these characteristics it is classified as a soil of good fertility. The studies were carried out on twenty plants at the proper stage for meiotic analysis. Flower buds were fixed in Carnoy for $24 \mathrm{hr}$, transferred to $70 \%$ alcohol, and stored at $5{ }^{\circ} \mathrm{C}$. Microsporocytes were prepared by the standard method used in meiotic studies and stained with $1 \%$ propionic carmine. All meiotic phases after diakinesis were analysed. Chiasma frequency was determined at diakinesis in twenty cells per plant. Abnormalities that might impair the meiotic product were taken into account. The number of seeds was evaluated in one hundred fruits.

\section{Results}

A total of 5.033 microsporocytes and 14.128 microspore tetrads were studied. Meiotic analysis revealed the presence of many abnormalities. Table 1 shows the frequency of these abnormalities from the pachytene phase to the tetrad stage. All pachytene microsporocytes showed perfect chromosome pairing. Starting from diakinesis $(2 n=28)$ it was possible to observe univalent chromosomes. The mean chiasma frequency per microsporocyte in diakinesis was $23.10(\mathrm{CV}=4.28 \%)$ and the mean interstitial chiasma frequency was $6.46(\mathrm{CV}=20.99 \%)$. There was a predominance of bivalents with two chiasmata. However, a mean of $5.45(\mathrm{CV}=$ $15.42 \%$ ) bivalents, among the fourteen extant, showed only one chiasma. In these bivalents a 
Table 1. Percentage of abnormal microsporocytes and number of cells analysed in each meiotic phase

\begin{tabular}{lcc}
\hline \hline \multicolumn{1}{c}{ Phase } & $\begin{array}{c}\text { \% of abnormal } \\
\text { microsporocyte }\end{array}$ & $\begin{array}{c}\text { Number of cells } \\
\text { analysed }\end{array}$ \\
\hline Pachytene & 0.00 & 350 \\
Diakinesis & 11.25 & 400 \\
Metaphase I & 33.27 & 1,644 \\
Anaphase I & 86.27 & 102 \\
Telophase I & 7.80 & 1,320 \\
Metaphase II & 21.51 & 423 \\
Anaphase II & 52.38 & 42 \\
Telophase II & 2.08 & 1,152 \\
Tetrads & 13.52 & 14,128 \\
\hline
\end{tabular}

Table 2. Frequency of developed seeds per fruit

\begin{tabular}{cc}
\hline \hline $\begin{array}{c}\text { Number of seeds } \\
\text { per fruit }\end{array}$ & Frequency of fruit \\
\hline 0 & 1 \\
1 & 2 \\
2 & 7 \\
3 & 13 \\
4 & 12 \\
5 & 14 \\
6 & 15 \\
7 & 9 \\
8 & 9 \\
9 & 9 \\
10 & 6 \\
11 & 3 \\
\hline
\end{tabular}

mean of $2.92(\mathrm{CV}=27.55 \%)$ were terminal chiasmata. Few bivalents showed three chiasmata (Fig. 1a). As a consequence of the presence of univalents, the meiotic behaviour was quite irregular. Precocious chromosome segregation was observed in metaphase I and II (Fig. 1b),

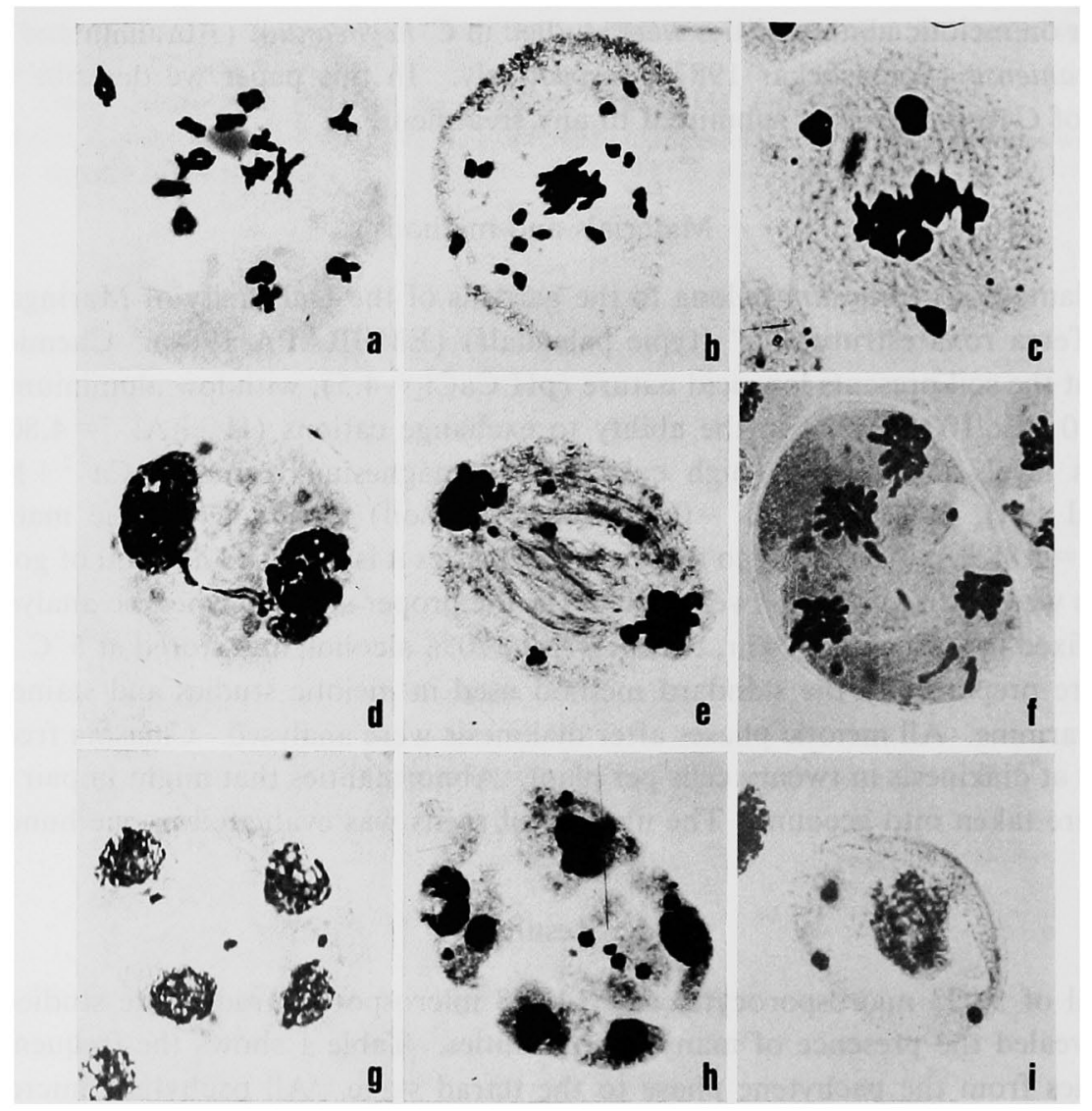

Fig. 1. Meiotic abnormalities in C. comosum. a) Microsporocyte at diakinesis showing fourteen bivalents with different numbers of chiasmata, b) Metaphase I showing univalents with precocious ascension, c) Metaphase I showing bivalents outside the spindle, d) Telophase I showing a double bridge, e, f) Anaphase I and II showing laggard chromosomes, g) Telophase II with micronuclei, h) Polyad showing microspores of different sizes and microspores with micronuclei, i) Microspore with three micronuclei. 


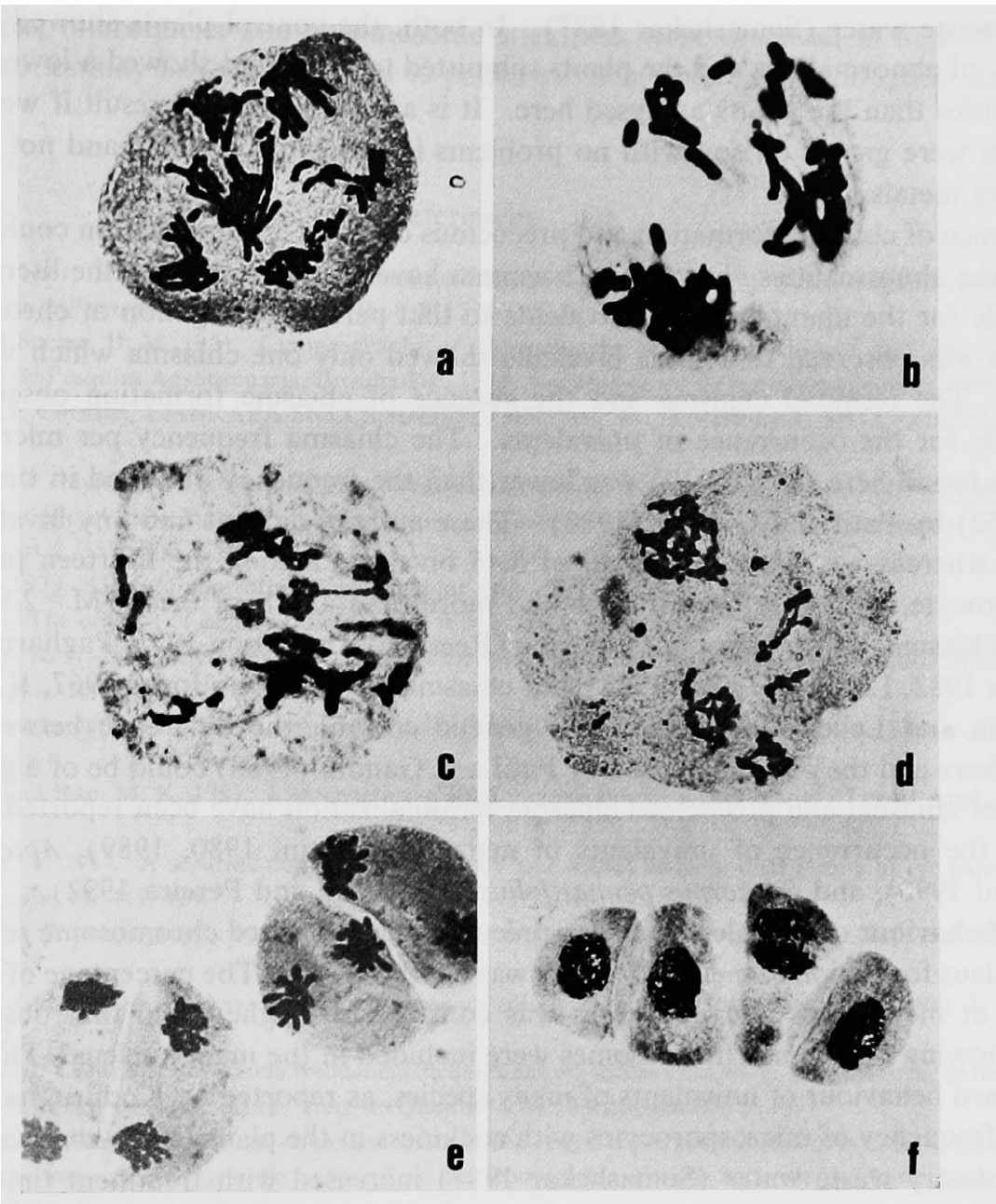

Fig. 2. Meiotic abnormalities in C. comosum. a) Microsporocyte in prophase I showing doubled chromosomes without pairing and chiasma, b) Microsporocyte in meiosis II showing total independence among chromatids, c, d) Anaphase I and prophase II with stickiness, e) Telophase II with a perpendicular spindle, f) Linear tetrad.

laggard chromosomes were observed in anaphase I and II (Fig. 1e, 1f) and micronuclei in telephase I and II (Fig. 1g). Bivalents outside the spindle in metaphase I (Fig. 1c), as well as single and double bridges (Fig. 1d) were very frequent. Other abnormalities such as absence of chiasma formation (Fig. 2a) leading to a total independence among chromosomes (Fig. 2b), and stickiness in all phases of meiosis I and II (Fig. 2c, 2d) were also observed at high frequency among microsporocytes. All these irregularities contributed to the formation of abnormal meiotic products which showed a large number of polyads and microspores with micronuclei (Fig. 1h, 1i). Perpendicular spindles were observed in many microsporocytes in telophase II (Fig. 2e) and linear tetrads among isobilateral ones also occurred (Fig. 2f). When the frequency of developed seeds per fruit was evaluated, a variation ranging from fruits without seeds to fruits with as many as eleven seeds was observed (Table 2).

\section{Discussion}

The same abnormalities found here were described in $C$. heyneanum treated with the fertilizer magnesium sulphate (Abraham and Nair 1990) and in C. amaniense treated with dye 
industry waste water (Somashekar 1987). In both, the control plants showed a much lower frequency of abnormalities and the plants submitted to treatment showed a lower frequency of abnormalities than the plants analysed here. It is a very interesting result if we consider that our plants were grown on soil with no problems in terms of nutrients and not contaminated with heavy metals.

Absence of chiasma formation and precocious chiasma terminalization could be the major cause of the abnormalities observed. Chiasmata have been discussed in the literature as being responsible for the maintenance of bivalents so that perfect segregation of chromosomes may occur. It was observed that some bivalents showed only one chiasma which was sometimes terminal. The terminal chiasma and the absence of chiasma formation observed could be responsible for the occurrence of univalents. The chiasma frequency per microsporocyte in diakinesis found here $(M=23.10)$ was lower than the frequency observed in the same species $(M=31.52)$ by Patil and Gandhi (1988). These authors did not find any bivalents with one chiasma, whereas we detected a mean of 5.45 bivalents among the fourteen present in each microsporocyte, with only one chiasma and more than a half of these $(M=2.92)$ showing a terminal chiasma. Since chiasma frequency (Rees and Thompson 1958, Pagliarini 1980, Karp and Jones 1982, Lein and Lelley 1987) and chiasma distribution (Jones 1967, Karp and Jones 1983, Lein and Lelley 1987) are under genetic control, the difference between the plants analysed here and the plants analysed by Patil and Gandhi (1988) could be of a genetic nature. Absence of chiasma and precocious chiasma terminalization have been reported to be responsible for the occurrence of univalents in maize (Pagliarini 1980, 1989), Aptenia cordifolia (Pagliarini 1990), and Pilocarpus pennatifolius (Pagliarini and Pereira 1992).

The behaviour of univalents causing precocious and delayed chromosome segregation and micronucleus formation in meiosis I and II was characteristic. The percentage of abnormalities observed at metaphases and anaphases was considerably higher than that observed at telophases, showing that some chromosomes were included in the main nucleus. This seems to be the standard behaviour of univalents of many species, as reported by Koduru and Rao (1981).

The frequency of microsporocytes with stickiness in the plants of $C$. amaniense submitted to dye industry waste water (Somashekar 1987) increased with treatment time and effluent concentration, whereas it was very low in the control. In our studies, the frequency of stickiness was high even though the plants were not submitted to any treatment. Some hypothesis have been postulated to explain the chromosome stickiness (Gaulden 1987), but none of them was tested in this work.

Meiotic abnormalities leading to the abnormal tetrad formation was described in Aptenia cordifolia (Pagliarini 1990a), Thunbergia mysorensis (Pagliarini 1990b), Pilocarpus pennatifolius (Pagliarini and Pereira 1992), and many other species. The presence of microcytes and micronuclei in microspores is a factor that leads to the formation of unbalanced gametes. The variability in number of seeds per fruit found here could be explained on the basis of the meiotic abnormalities observed, as was the case for Pilocarpus pennatifolius (Pagliarini and Pereira 1992) and Ochna sp (Pagliarini et al. 1992). The meiotic abnormalities described are not specific for $C$. comosum. They are found frequently in others species. In general, these abnormalities affect the pollen fertility and the seed production as a consequence. These data reinforce once again that seed production depends on the regularity of the meiotic process among other factors.

\section{Summary}

The meiotic behaviour of flower buds of Chlorophytum comosum grown under natural conditions without any treatment was evaluated. Many abnormalities such as univalents, 
laggards, bridges, micronuclei and chromosome stickiness were observed at high frequency. These abnormalities may have contributed to pollen sterility since seed production was highly affected.

\section{References}

Abraham, S. and Nair, R. B. 1990. Meiotic abnormalities produced by the fertilizer magnesium sulphate in Chlorophytum heyneanum. J. Environ. Biol. 11: 279-283.

Baldwin, J. T. and Speese, B. M. 1951. Cytogeography of Chlorophytum in Liberia. Amer. J. Bot. 38: 153-156

Empresa Brasileira de Pesquisa Agropecuaria, Brasília-DF. 1984. Levantamento de reconhecimento de solos do Estado do Paraná. Curitiba, EMBRAPA-SNLCS/SUDESUL/IAPAR. 2v. (EMBRAPA, SNLCS. Boletim Técnico, 57)

Gaulden, M. E. 1987. Hypothesis: some mutagens directly alter specific chromosomal proteins (DNA topoisomerase II and peripheral proteins) to produce chromosome stickiness, which causes chromosome aberrations. Mutagenesis 2: $357-365$.

Goluborskaya, N. 1979. Genetic control of meiosis. Inter. Rev. Cytol. 58: 247-290.

Jones, G. H. 1967. The control of chiasma distribution in rye. Chromosoma 22: 69-90.

Karp, A. and Jones, R. N. 1982. Cytogenetics of Lolium perenne. Part I. Chiasma frequency variation in inbred lines. Theor. Appl. Genet. 62: 177-183.

- and - 1983. Cytogenetics of Lolium perenne. Part II. Chiasma distribution in inbred lines. Theor. Appl. Genet. 64: $137-145$.

Koduru, P. R. K. and Rao, M. K. 1981. Cytogenetics of synaptic mutants in higher plants. Theor. Appl. Genet. 59: 197-214.

Lein, V. and Lelley, T. 1987. A separate control for frequency and within-bivalent distribution of rye (Secale cereale L.). Genome 29: 419-424.

Mukherjee, N. 1975. Phytogeography and phylogeny of Chlorophytum Ker-Gawl (Liliaceae). Bull. Bot. Soc. Bengal. 29: $75-82$.

Naik, V. N. 1976. Chromosomal behaviour and evolutionary trends in Chrolophytum (Liliaceae). Bot. J. Linn. Soc. 72: 45-50.

Pagliarini, M. S. 1980. Controle genético da freqüència de quiasmas em milho (Zea mays L.). Dissertaçào de Mestrado -Escola Superior de Agricultura "Luiz de Queiroz"/USP, Piracicaba-SP, $113 \mathrm{p}$

- 1989. Avaliação da frequiencia de quiasmas em milho (Zea mays L.) e suas implicaçòes com a capacidade de combinação para a produçõo de grãos. Tese de Doutorado-Escola Superior de Agricultura "Luiz de Queiroz"/USP, Piracicaba-SP, $190 \mathrm{p}$.

- 1990a. Meiotic behaviour and pollen fertility in Aptenia cordifolia (Aizoaceae). Caryologia 43: 157-162.

- 1990b. Instabilidade meiótica em Thunbergia mysorensis (Acanthaceae). Ciência e Cultura 42: 83-87.

-. Martinez, M. and Silva, I. 1992. Some observations on the cytology in Ochna sp (Ochnaceae). Cytologia 57: 237240.

- and Pereira, M. A. S. 1992. Meiotic studies in Pilocarpus pennatifolius Lem. (Rutaceae). Cytologia 57: 231-235.

Patil, V. P. and Gandhi, S. S. 1988. Inter-specific variations in chiasma frequency and terminalization in Chlorophytum Ker-Gawl. Cytologia 53: 571-575.

-, Kumbhojkar, M. S. and Gandhi, S. S. 1987. Karyomorphological studies in Chlorophytum Ker-Gawl. Cytologia 52: $543-550$.

Rees, H. and Thompson, J. B. 1958. Genotypic control of chromosome behaviour in rye. V. The distribution pattern of chiasmata between pollen mother cells. Heredity 12:101-111.

Somashekar, R. K. 1987. Meiotic abnormalities induced by dye industry waste water in Chlorophytum amaniense Engler. Cytologia 52: 647-652.

Tarafder, C. R. 1983. Ethnogynecology in relation to plants: 2. Plants used for abortion. J. Econ. Taxon. Bot. 4: 507516.

Wolverton, B. C., McDonald, R. C. and Watkins Jr., E. A. 1984. Foliage plants for removing indoor air pollutants from energy-efficient homes. Econ. Bot. 38: 224-228. 